Abstracta Iranica Abstracta Iranica

Revue bibliographique pour le domaine irano-aryen

Volume 28 | 2007

Comptes rendus des publications de 2005

\title{
The Iranian Labyrinth. Journeys through Theocratic Iran and its Furies. New York, Nation Books, 2005, $418 \mathrm{p}$.
}

\section{Azadeh Kian-Thiébaut}

\section{(2) OpenEdition}

1 Journals

Édition électronique

URL : http://journals.openedition.org/abstractairanica/18981

DOI : 10.4000/abstractairanica.18981

ISSN : 1961-960X

Éditeur :

CNRS (UMR 7528 Mondes iraniens et indiens), Éditions de l'IFRI

Édition imprimée

Date de publication : 15 mai 2007

ISSN : 0240-8910

Référence électronique

Azadeh Kian-Thiébaut, «The Iranian Labyrinth. Journeys through Theocratic Iran and its Furies. New York, Nation Books, 2005, 418 p. », Abstracta Iranica [En ligne], Volume 28 | 2007, document 418, mis en ligne le 18 septembre 2007, consulté le 25 septembre 2020. URL : http://journals.openedition.org/ abstractairanica/18981; DOI : https://doi.org/10.4000/abstractairanica.18981

Ce document a été généré automatiquement le 25 septembre 2020

Tous droits réservés 


\title{
The Iranian Labyrinth. Journeys through Theocratic Iran and its Furies. New York, Nation Books, 2005, 418 p.
}

\author{
Azadeh Kian-Thiébaut
}

1 Célèbre journaliste originaire du sub-continent indien, l'A. s'est rendu fréquemment en Iran après la révolution pour le compte de la presse américaine et anglaise. A travers un aperçu historique, le présent ouvrage souligne les particularités géopolitiques, stratégiques, historiques et culturelles de l'Iran présenté comme le pays des paradoxes.

2 Pour l'A., la révolution iranienne ou la participation de millions d'Iraniens au processus de renversement du régime du chah constitue une particularité au Moyen-Orient dans la mesure où les changements politiques en Égypte, en Iraq ou au Yémen n'étaient pas l'œuvre de soulèvements populaires mais de juntes militaires. L'A. souligne le rôle singulier de Homeynī dans la consolidation de la République islamique, arguant que grâce à son autorité religieuse, à son charisme et à sa synthèse entre l'islam et le nationalisme la nation iranienne a résisté à l'invasion irakienne. Pour l'A., Hुomeynī a consolidé son pouvoir au travers de son contrôle du gouvernement, des media et du réseau chi'ite, et n'a pas hésité à éliminer ou à neutraliser ses opposants laïques ou religieux.

3 Selon D. Hiro, le système politique de la République islamique continue à diviser les observateurs. Pour les uns, le système est si profondément autoritaire qu'il est imperméable au changement. Pour les autres, la lutte entre les réformateurs et les conservateurs constitue la dynamique de la démocratie islamique que les dirigeants iraniens tentent de créer comme modèle inédit pour le monde musulman. L'A. affirme que la lenteur des changements institutionnels est imputable aux mécanismes de contrôle des pouvoirs inscrits dans la constitution iranienne et qui dépassent largement ceux de beaucoup de pays occidentaux. 
4 Pour l'A., le bilan du régime islamique est positif dans plusieurs domaines, en particulier celui de l'éducation des femmes. La révolution a conféré beaucoup de pouvoir à la petite bourgeoisie et à la classe ouvrière, des rangs desquels sont issus les Gardiens de la révolution et les basijisis. Enfin, le régime islamique a fait de l'Iran un État indépendant qui parle aux géants européen, chinois ou indien d'égal à égal. C'est la raison pour laquelle les Iraniens, tant les dirigeants que le peuple, rejettent les ingérences des États-Unis dans leurs affaires intérieures. Pour l'A., Téhéran et Washington se sont affrontés sur la question de la direction régionale. La stratégie à long terme des États-Unis consiste en effet à ne permettre à aucun Etat de devenir la puissance dominante dans la région du golfe Persique.

5 Rédigé avant les présidentielles de juin 2005, l'ouvrage voit Hāšemī-Rafsanjānī, 'Alī Lārijānī et Ḥasan Rūhānī comme principaux candidats des conservateurs. L'A. estime que ces derniers, ayant le contrôle des trois organes de l'État, accepteront des compromis sur les réformes sociales et économiques mais garderont le monopole du pouvoir politique.

\section{INDEX}

Thèmes : 13.1. Iran

\section{AUTEURS}

\section{AZADEH KIAN-THIÉBAUT}

Université Paris VIII / Mondes iranien et indien 